\title{
On Capital Flight from the ASEAN-8 Countries: A Panel Data Estimation
}

\author{
Navik ISTIKOMAH ${ }^{1}$, Indra SUHENDRA ${ }^{2}$, Cep Jandi ANWAR ${ }^{3}$
}

Received: September 01, 2020 Revised: October 26, 2020 Accepted: November 05, 2020

\begin{abstract}
This paper examines how macroeconomic variables, such as interest rate differences, inflation, exchange rates, economic growth and external debt growth, affect capital flight in the ASEAN-8 countries. We apply a panel data model with fixed effect estimation for the data for eight countries from the period 1994 to 2018. We use the residual approach used by the World Bank to measure the value of capital flight. The results show that the interest rate differences, exchange rates, economic growth and foreign debt growth had a positive and significant effect on outward capital flight. A further implication of this finding is that the interest rate differences, exchange rate, economic growth and foreign debt growth are factors that trigger an increase in capital outflow in the ASEAN-8 countries. Nonetheless, inflation rate is not considered to be the main factor influencing capital flight, as average inflation in the ASEAN-8 countries remains relatively stable. This paper will be beneficial for policymakers in the ASEAN-8 countries and encourage them to constantly pay attention to these four variables, as they significantly influence capital flight, whereas they can disregard the impact of the inflation variable that is not significant in influencing capital flight.
\end{abstract}

Keywords: Capital Flight, Inflation, Exchange Rate, The ASEAN-8 countries, Panel Data

JEL Classification Code: E31, F21, F31

\section{Introduction}

Capital flight has actually been discussed by many researchers. However, there is no general definition of capital flight which can be accepted by all economists. Generally, there are three approaches to measure capital flight: the computational approach to balance of payments

${ }^{1}$ First Author and Corresponding Author. Assistant Professor, Economics Education Department, Universitas Pendidikan Indonesia, Bandung, Indonesia [Postal Address: Jalan Setiabudi 229, Bandung City, West Java, 40154, Indonesia] Email: navik.istikomah@upi.edu ${ }^{2}$ Assistant Professor, Department of Economics and Development Studies, Universitas Sultan Ageng Tirtayasa, Banten, Indonesia. Email: indras_23@untirta.ac.id

${ }^{3}$ Assistant Professor, Department of Economics and Development Studies, Universitas Sultan Ageng Tirtayasa, Banten, Indonesia. Email: cepjandianwar@untirta.ac.id

(c) Copyright: The Author(s)

This is an Open Access article distributed under the terms of the Creative Commons Attribution Non-Commercial License (https://creativecommons.org/licenses/by-nc/4.0/) which permits unrestricted non-commercial use, distribution, and reproduction in any medium, provided the original work is properly cited.
(Cuddington, 1986), residual approach (Erbe, 1985) and the bank deposit approach. The computational approach to balance of payments is a traditional approach that focuses on the balance of payments component. The residual approach estimates capital flight as residual. Meanwhile, the bank deposit approach is a capital flight measure based on the increase in foreign bank deposits reported by domestic residents.

Since 1985, the World Bank has used a residual approach to measure capital flight (Erbe, 1985). In this approach, capital flight is calculated by the difference in residual between capital inflows (in the form of increased foreign direct investment and foreign debt) and capital outflows (deficits in relation to current accounts and changes in foreign exchange reserves), so that the residual of both is indicated as capital flight. The residual approach as a measurement of capital flight remains relevant, particularly in developing countries, where most development funds rely on foreign debt and foreign direct investment, including the ASEAN-8 countries (Indonesia, Malaysia, Thailand, the Philippines, Vietnam, Myanmar, Cambodia and Laos). 
In Table 1, we can see the average ratio of capital flight to total external debt in the ASEAN-8 countries during the period 2009 to 2018, which shows a positive number for Indonesia (0.16), Vietnam (0.25), Myanmar (0.29), Cambodia (0.49) and Laos (0.26), while for Malaysia, Thailand and the Philippines, the average ratio of capital flight to total external debt reveals a negative number, i.e., $-0.05,-0.08$ and -0.04 , respectively. The positive number shows that every additional increase in total foreign debt of USD 1 million will increase the value of outward capital flights by USD 0.16 million in Indonesia, by USD 0.25 million in Vietnam, by USD 0.29 million in Myanmar, by USD 0.49 million in Cambodia and by USD 0.26 million in Laos.

Now we can see the average ratio of capital flight to changes in external debt. Table 1 confirms the positive numbers for Indonesia (2.40), Thailand (0.21), the Philippines (0.36), Vietnam (1.79), Cambodia (3.14) and Laos (2.82). Meanwhile, for Malaysia and Myanmar, the average ratios were negative -0.74 and -15.13 , respectively. The positive numbers show that each additional external debt increase of USD 1 million will increase the value of outward capital flight by USD 2.40 million in Indonesia, by USD 0.21 million in Thailand, by USD 0.36 million in the Philippines, by USD 1.79 million in Vietnam, by USD 3.14 million in Cambodia and by USD 2.82 million in Laos. Otherwise, the negative figure confirms that every additional foreign debt increase of USD 1 million will encourage inward capital flight of USD 0.74 million in Malaysia and USD 15.13 million in Myanmar. This indicates that changes in total foreign debt and additional external debt have different effects (both positive and negative), on the value of capital flight in the ASEAN-8 countries.

It is important to note that several factors affect capital flight apart from external debt. Previous studies have shown that macroeconomic variables, such as interest rates differences, inflation, exchange rates, economic growth and foreign debt growth are the main factors that can significantly influence capital flight. This paper will use the residual approach employed by the World Bank to measure capital flight in the ASEAN-8 countries. The residual approach has also been employed by Dooley (1986), Collier et al., (2004), Vespignani (2008), Okoli and Akujuobi (2009), Al-Fayoumi et al., (2012) and Ozer et al., (2013). The aim of this paper is to obtain empirical evidence regarding the macroeconomic variables which have a significant effect on capital flight in the ASEAN-8 countries, by way of using panel data from the ASEAN-8 countries from 1994 to 2018.

\section{Literature Review}

In defining capital flight, each expert has used his/ her own concept. The definition of capital flight was first suggested by the World Bank (Erbe, 1985). According to the World Bank, capital flight is calculated as a residual, which is the difference between capital inflow and the use of capital. Capital inflow consists of increases in external debt and foreign direct investment, whilst the use of capital is to cover the current account deficit and changes in foreign exchange reserves. The residual reflects the net invoices of the private sector abroad and at home.

Cuddington (1986), defines capital flight as the shortterm outflow of capital, both recorded as well as unrecorded and acknowledged as risky by the non-banking sector. These short-term capital outflows are caused by the uncertainty of the economic or political situation in the country or for speculative purposes. Cuddington measures capital flight as recorded short-term capital outflows and net errors and omissions as capital outflows that are not recorded on the balance of payments.

Table 1: Average Capital Flight Ratio to External Debt and Changes in External Debt in the ASEAN-8 Based On the Residual Approach for 2009-2018

\begin{tabular}{|l|c|c|}
\hline Country & Capital Flight Ratio to External Debt & Capital Flight Ratio to Changes in External Debt \\
\hline Indonesia & 0.16 & 2.40 \\
\hline Malaysia & $-0,05$ & $-0,74$ \\
\hline Thailand & -0.08 & 0.21 \\
\hline Philippines & -0.04 & 0.36 \\
\hline Vietnam & 0.25 & 1.79 \\
\hline Myanmar & 0.29 & -15.13 \\
\hline Cambodia & 0.49 & 3.14 \\
\hline Laos & 0.26 & 2.82 \\
\hline
\end{tabular}

Source: World Bank, Data Processed, 2019 
An additional definition of capital flight was given by Khan and Haque (1987), who defined capital flight as all capital outflows from developing countries which lead to the loss of potential available capital resources and economic growth, regardless of the background of the occurrence of the flow of capital from within the country. There are three concepts concerning capital flight measurement approaches that are commonly employed. First, the balance of payments computational approach is a traditional method that focuses on the balance of payments component. This approach is used by Cuddington (1986) to estimate capital flight using the equation:

$$
\mathrm{CF}=-\mathrm{G}-\mathrm{C}
$$

where $\mathrm{CF}$ is capital flight, $\mathrm{C}$ is short-term capital flow and $\mathrm{G}$ is error and omission.

The weakness associated with this method lies in the net error and omissions component which is used to record transactions between countries that have not been accommodated by other components due to various accounting errors and time lags that are difficult to avoid. Thus, this is a component of the balance of payments balance. When this component is presented in net form, it will become increasingly difficult to identify whether the net error and omission value originates from recording errors in exports, imports or capital flows.

Second, the residual approach, as applied by the World Bank in compiling the World Development Report (Erbe, 1985), estimates capital flight as residual, which measures the residuals from sources of funds and the use of funds. The difference between the two is referred to as residual. Sources of funds include all net official inflows (increase in public sector net external debt) and net flows of foreign direct investment. Users of funds include current account deficits and changes in foreign exchange reserves (Phan and Nguyen, 2020). Capital flight out occurs when the source of funds exceeds the use of funds and vice versa for the flight of capital in, so that the residuals of both are indicated as outward or inward capital flights. The equations for this approach are:

$$
\begin{gathered}
\mathrm{CF}=(\mathrm{H}+\mathrm{B})-(\mathrm{A}+\mathrm{F}) \\
\mathrm{CF}=(\Delta \mathrm{ED}+\Delta \mathrm{FDI})-(\mathrm{CA}+\Delta \mathrm{OR})
\end{gathered}
$$

where $\mathrm{CF}$ is capital flight, $\mathrm{H}$ or $\triangle \mathrm{ED}$ is the change in external debt, $\mathrm{B}$ or $\triangle \mathrm{FDI}$ is net private direct investment, $\mathrm{A}$ or $\mathrm{CA}$ is the current account (surplus/deficit) and $\mathrm{F}$ or $\Delta \mathrm{OR}$ is the change in foreign exchange reserves.

The third is termed as the bank deposit approach. This approach is a calculation of capital outflows, which includes measuring the increase in recorded foreign bank deposits held by domestic residents. However, in most cases the amount of deposits recorded with banks is smaller than the cumulative estimate of resident capital outflows. In other words, statistics for bank deposits often underestimate the number of funds held outside. The flaw in this approach is that depositors do not always report their deposits correctly or that there are funds stored in other assets besides deposits.

Based on the three approaches, the measurement of capital flight used in our study is based on the residual approach, specifically the amount of residual value indicates the net difference from the source of funding to the use of funds. The use of the residual concept relates to the use of funding sources from the ASEAN-8 countries which are commonly employed as a source of development, which of course will have various consequences, both positive and negative.

Furthermore, to construct a capital flight model, in this paper we consider three main theories. First is the international capital flow approach. The movement of capital between countries continuously considers high expectations or returns if the capital is invested in new locations. Therefore, shifting investment capital is always carried out in a vehicle that can increase profits. The rate of profit is the level of expected profit in the future, where the expected profit is reflected by the amount of profit that will be obtained, as well as the level of risk that is expected to occur in the future. In several studies, interest rate and inflation are consistently used as proxies of the amount of profit and the level of risk. Meanwhile, for foreign investors, in addition to interest and inflation, changes in exchange rates are also a factor for calculating risk, while the economic growth of a country is also considered a potential gain (Nantharath and Kang, 2019). Changes in exchange rates (depreciation and appreciation) will affect the amount of investment in an investment area (Qamruzzaman et al., 2020). However, economic growth is regarded as a possible business development in the future. Based on this approach, capital flight $(\mathrm{CFt})$ depends on the difference in interest rates (DINT), inflation rates (INF), exchange rates (ER) and economic growth (GRT).

Second, the investment portfolio theory, states that an investor prefers a higher income but dislikes risk. Hence, investors tend to favour investments that generate high income with the least risk. The basic motive for international portfolio investment according to Krugman and Obstfel (2009), is to obtain a greater profit from the activity of storing assets in domestic assets or foreign assets and is dependent on the interest rates offered from deposits for both assets $\left(i, i^{*}\right)$. Based on this approach, 
capital flight $\left(\mathrm{CF}_{t}\right)$ depends on the value of the difference in interest rates (DINT) on deposits of domestic assets and foreign assets.

Third, the interest rate parity theory, which says that in the long run there will no longer be obstacles in the flow of capital, which is to say that the national economy is integrated with the world economy. In this condition, 'law of one price' actually applies, namely interest between countries in the free foreign exchange system is basically the same where investment in each country will provide the same level of profit due to the same interest in both countries enabling a perfect transfer of funds (Batiz and Luiz, 1994). In this context, it signifies that domestic investors can freely choose whether to invest their funds in domestic assets or in foreign assets to generate the same level of profit. Likewise, debtors who require funds can freely choose whether to make a domestic loan or a foreign loan, because both loan funds are subject to the same cost. If there is a difference in interest rates between two assets, this is due to differences in the exchange rates of the two countries or the estimated depreciation value. However, in countries that adopt a non-free foreign exchange system, it is possible that the domestic asset interest rate is exceedingly different from the foreign asset interest rate, even though it has been corrected by the estimated depreciation rate (Tung and Thang, 2020). Therefore, according to the interest rate parity theory, capital flight $\left(\mathrm{CF}_{t}\right)$ is influenced by the difference in interest rates (DINT) and exchange rate depreciation (ER).

The growth of foreign debt is also considered to be a factor affecting capital flight. Harrigan et al., (2002), Quazi (2004), Al-Fayoumi et al. (2012), Ahmad and Sahto (2016), Wujung and Mbella (2016) and Uddin et al., (2017), assert that the growth of external debt has a positive effect on capital flight. This implies that the higher the growth of foreign debt, the higher the capital flight due to capital inflows from larger foreign debt. Only a small proportion of researchers stated the opposite, such as Schineller (1997), Liew et al., (2016) and Ozer et al., (2013).

\section{Data and Methodology}

\subsection{Data}

This study uses panel data for ASEAN-8 countries with annual data from 1994 to 2018. The data is obtained from World Bank publications. The estimation of the scale of capital flight in this study uses the residual approach used by the World Bank (Erbe, 1985), which is the amount of residual value that indicates the net difference between the source of funding and the use of funds. Sources of funds include all net official inflows (increase in net public sector external debt) and net foreign direct investment flows. The use of funds include current account deficits and additional reserves. Outward capital flight occurs when the source of funds exceeds the use of funds and vice versa for inward capital flight.

The difference in interest rates is the difference between the domestic deposit interest rates in each of the ASEAN-8 countries and the treasury bill interest rates in the United States. Inflation is calculated based on the consumer price index for each country. The exchange rate is the nominal exchange rate in effect in ASEAN-8 countries against the US dollar. Economic growth is the growth of GDP in the current year in ASEAN-8 countries, which is measured based on constant prices for 2010. Growth in external debt represents the magnitude of the growth in external debt in ASEAN-8 countries.

Table 2 shows the variables that will be used in this study for the twenty-five year period.

\subsection{Econometrics Methodology}

The econometric methodology used in our model in equation (4) is a multiple regression equation model using panel data, which is a combination of time series and crosssection data. To obtain the best panel model, which is the common effect model, fixed effect and random effect models will be tested by performing Chow and Hausman tests. In our research model equation, we will test classical assumptions and other necessary tests.

Table 2: Descriptive Statistics

\begin{tabular}{|l|c|c|c|c|}
\hline Variable & Mean & Std Dev. & Min. & Max. \\
\hline CF & 3184.994 & 18042.82 & -50188.08 & 80315.46 \\
\hline DINT & 4.18 & 4.39 & -2.88 & 34.25 \\
\hline INF & 8.14 & 13.49 & -1.71 & 125.27 \\
\hline ER & 4661.28 & 6058.14 & 2.50 & 22602.05 \\
\hline GRT & 6.14 & 3.27 & -13.13 & 13.84 \\
\hline GDEBT & 6.96 & 11.18 & -44.96 & 52.59 \\
\hline
\end{tabular}


In this study, we suppose that that various variables have a significant effect on capital flight. Cuddington (1986), uses expected exchange rate, inflation and interest rates. The results of his research show that capital flight in Argentina, Brazil, Chile, Korea, Mexico, Peru, Uruguay and Venezuela is determined by exchange rate expectations, inflation rates and interest rates, both positively and negatively. Harrigan et al., (2002), use real exchange rate variables, changes in foreign debt, economic growth and inflation for measuring capital flight based on four measurements; Dooley, World Bank, Private Claim's and Balance of Payments. The conclusion of their research is that they noticed different effects of each explanatory variable on capital flight in the four measurements. Al-Fayoumi et al., (2012) applied the variables of external debt, economic growth, uncertainty, foreign direct investment, exchange rates, inflation and interest rate differences as determinants of capital flight in Jordan, Syria, Algeria, Morocco, Egypt, Turkey and Tunisia. The results of their empirical study ascertained that there is a negative and insignificant effect of economic growth, real exchange rate, inflation and differences in interest rates on capital flight in these countries.

However, foreign debt, uncertainty and foreign direct investment have a positive effect on capital flight. Ahmad and Sahto (2016), analysed the determinants of capital flight in Pakistan by using variables of foreign direct investment, inflation, economic growth, foreign exchange reserves, exchange rates and foreign debt to capital flight. The results of their research indicates that the foreign exchange reserve has a negative and significant impact on capital flight. Nevertheless, other variables have a positive and significant effect on capital flight. In their research, Liew et al., (2016), made use of the variables like foreign direct investment, foreign debt, capital markets and political risk as determinants of capital flight in Malaysia. The results of their research shows that the political risk variable has a positive effect on capital flight, while the variables of foreign direct investment, foreign debt and capital market have a negative effect on the variable of capital flight. Uddin et al., (2017), used the external debt, foreign direct investment, foreign exchange reserves, interest rate differences, balance of payments surplus, and inflation, together with economic growth as variables for determining capital flight in Bangladesh. The results of their research indicate that foreign exchange reserves, economic growth and a balance of payments surplus have a negative effect on capital flight, whilst foreign debt, foreign direct investment, differences in interest rates and inflation have a positive effect on capital flight in Bangladesh.

Furthermore, the results of research undertaken by Schineller (1997) and Quazi (2004), found a negative effect of interest rate differences on capital flight. Conversely,
Vespignani (2008), established the opposite. Ozer et al., (2013), reveal empirical evidence of a negative and significant effect for inflation on capital flight, indicating that the higher the inflation the lower capital flight. However, Wujung and Mbella (2016) demonstrate contradictory empirical evidence claiming that inflation has a positive and significant effect on capital flight.

Wujung and Mbella (2016) found empirical results which show that exchange rate has a positive effect on capital flight. Meanwhile, Ozer et al., (2013), established empirical results that are opposite and maintain that exchange rate has a negative effect on capital flight. Okoli and Akujuobi (2009), noticed the positive and significant effect of differences in interest rates, economic growth and inflation on capital flight. Quazi (2004) in their empirical studies stated that economic growth has a negative effect on capital flight.

Furthermore, Quazi (2004) and Wujung and Mbella (2016) state that the growth of foreign debt has a positive effect on capital flight. This indicates that the higher the growth of foreign debt, the higher the capital outflow. This occurs due to capital inflows from larger foreign debt. Meanwhile, Schineller (1997), Liew et al., (2016) and Ozer et al., (2013) assert that the higher the growth of foreign debt, the lower the capital outflow.

In this study, we use various macroeconomic variables that are expected to have an influence on capital flight as the empirical results above demonstrate. Thus, our model is described as follows:

$$
\begin{aligned}
C F_{i t}= & \alpha_{i}+\beta_{1} D I N T_{i t}+\beta_{2} I N F_{i t}+\beta_{3} E R_{i t}+\beta_{4} G R T_{i t} \\
& +\beta_{5} G D E B T_{i t}+\varepsilon_{i t}
\end{aligned}
$$

where $\mathrm{i}=1,2, \ldots, \mathrm{N}$ for countries cross-section, $\mathrm{t}=1,2, \ldots$, $\mathrm{T}$ for time series, CF describes capital flight, DINT shows differences in interest rates, INF is the rate of inflation, ER is the exchange rate, GRT is economic growth, GDEBT is the growth of external debt, and $\alpha_{i}$ is the sectoral specification effect.

\section{Empirical Results}

\subsection{Result of Chow and Hausman Tests}

In Table 3, we can see the results of the Chow and Hausman tests for this research model. Based on the Chow test, the Prob. Cross-section Chi Square < alpha (5\%) or $0,0043<0.05$, meanwhile for the Hausman test, it shows that the value of the Prob. Cross-section Random < alpha $(5 \%)$ or $0.0021<0.05$. Based on these two tests, it can be concluded that the best panel data regression estimation model that can be used for the research model is the fixed effect model (FEM). 
Table 3: Result of Chow and Hausman Tests

\begin{tabular}{|c|c|c|c|}
\hline Num. & Testing & Value & Conclusion \\
\hline \multirow[t]{3}{*}{1.} & \multicolumn{3}{|l|}{ Chow test } \\
\hline & Cross-section chi-square & 20.683 & \multirow{2}{*}{ fixed effect model (FEM) } \\
\hline & Prob. & 0,0043 & \\
\hline \multirow[t]{3}{*}{2.} & Hausman test & & \\
\hline & Cross-section random & 18.7683 & \multirow{2}{*}{ fixed effect model (FEM) } \\
\hline & Prob. & 0.0021 & \\
\hline
\end{tabular}

Table 4: Result of Multicollinearity Test

\begin{tabular}{|l|c|c|c|c|c|}
\hline & DINT & INF & LNER & GRT & GDEBT \\
\hline DINT & 1.0000 & 0.4651 & 0.2375 & -0.18212 & 0.0853 \\
\hline INF & 0.4651 & 1.0000 & 0.0452 & 0.0017 & -0.0214 \\
\hline LNER & 0.2375 & 0.0452 & 1.0000 & 0.0370 & 0.0708 \\
\hline GRT & -0.1822 & 0.0017 & 0.0370 & 1.0000 & 0.0813 \\
\hline GDEBT & 0.0853 & -0.0214 & 0.0708 & 0.0813 & 1.0000 \\
\hline
\end{tabular}

Table 5: Result of Heteroscedasticity, Autocorrelation and Normality Tests

\begin{tabular}{|c|c|c|c|}
\hline Num. & Testing & Value & Conclusion \\
\hline \multirow[t]{5}{*}{1.} & \multicolumn{3}{|c|}{ Heteroskedasticity (White test) } \\
\hline & n-observed & 200 & \multirow{4}{*}{$\begin{array}{c}X_{\text {count }}^{2}<X_{26: 0.05}^{2} \\
\text { no heteroscedasticity }\end{array}$} \\
\hline & $r$-squared & 0.1205 & \\
\hline & Chi Square count & 24.1124 & \\
\hline & Chi Square table $(20 ; 0.05)$ & 31.4104 & \\
\hline \multirow[t]{6}{*}{2.} & \multicolumn{3}{|c|}{ Autocorrelation (Durbin-Watson test) } \\
\hline & Durbin-Watson count & 2.0357 & \multirow{5}{*}{$\begin{array}{c}\mathrm{D}_{U}<2.0357<4-\mathrm{D}_{U} \\
\text { no autocorrelation }\end{array}$} \\
\hline & Nilai $D_{L}$ & 1.7180 & \\
\hline & Nilai $\mathrm{D}_{u}$ & 1.8200 & \\
\hline & Nilai 4-D $\mathrm{D}_{u}$ & 2.1800 & \\
\hline & Nilai $4-D_{L}$ & 2.2282 & \\
\hline \multirow[t]{3}{*}{3.} & Normality (Jarque-Bera tes & & \\
\hline & Jarque-Bera & 0.7511 & \multirow{2}{*}{ normally distributed } \\
\hline & Prob. & 0.6868 & \\
\hline
\end{tabular}

\subsection{Result of Classical Assumption and Normality Tests}

In relation to our model, it is necessary to test classic assumptions (multicollinearity, heteroscedasticity and autocorrelation) and a normality test to determine the validity of the data. Table 4 presents the correlation matrix to detect the presence or absence of multicollinearity problems in the data. It is said that there is a multicollinearity problem if there is a correlation between the independent variables greater than 0.80 . Table 4 indicates the overall magnitude of the correlation between the independent variables whose value is less than 0.80 . Thus, it can be concluded that there is no multicollinearity problem in the data or linear relationship with a high coefficient between independent variables.

Table 5 presents the White test results to detect the presence of heteroscedasticity problems, the results of the Durbin-Watson test to detect the presence of autocorrelation 
problems and the Jarque-Berra test to determine whether or not the residuals of the research model have been normally distributed. The conclusion that can be drawn from the test results is that the research model is free from heteroscedasticity problems and autocorrelation problems, whereas the research equation applied has residual values with normally distributed data distribution.

\subsection{Result of the Fixed Effect Model}

Table 6 shows the result of panel data estimation using the fixed effect model. Except for the inflation variable, all independent variables consist of differences in interest rates, exchange rates, economic growth and growth in external debt which have a positive and significant sign in relation to capital outflow. The inflation variable has a negative effect but is not significant concerning capital outflow. Nevertheless, the variable for differences in interest rates, exchange rates, economic growth and growth of foreign debt to capital outflows have different significance levels. We can also notice the results of the determination coefficient $\left(\mathrm{R}^{2}\right)$ and the adjusted coefficient of determination (adjusted $\mathrm{R}^{2}$ ), where the $\mathrm{R}^{2}$ is 0.4378 and $\mathrm{Adj} . \mathrm{R}^{2}$ is 0.4017 . This shows that all independent variables are able to explain the variation of changes in capital outflow by $43.78 \%$ or $40.17 \%$ after adjustment, whereas the remaining $56.28 \%$ or $59.83 \%$ after adjustment, is explained by variations in other variables that are not included in the model in this study. Table 6 of the fixed effect model also produces an F-statistics value of 12.41 and it is significant at the $1 \%$ level. This result confirms that together at the $1 \%$ level, all independent variables have a significant effect on the dependent variable.

Table 6: Fixed Effect Estimation

\begin{tabular}{|l|c|c|c|}
\hline Variable & Estimate & t-Statistics & Prob. \\
\hline DINT & 405.707 & 2.4310 & $0.0160^{* *}$ \\
\hline INF & -3.2857 & -0.1262 & 0.8997 \\
\hline ER & 1.0610 & 4.7170 & $0.0000^{* * *}$ \\
\hline GRT & 620.183 & 3.5592 & $0.0005^{* * *}$ \\
\hline GDEBT & 204.7018 & 5.1694 & $0.0000^{* * *}$ \\
\hline Constant & -8670.956 & -4.2278 & $0.0000^{* * *}$ \\
\hline R $^{2}$ & 0.4378 & & \\
\hline Adj. $\mathrm{R}^{2}$ & 0.4017 & & \\
\hline F-statistic & & 12.1341 & $0.0000^{* * *}$ \\
\hline Durbin-Watson stat & 2.0357 & & \\
\hline
\end{tabular}

Notes:

1. The dependent variable is capital flight.

2. The symbols * ${ }^{* *},{ }^{* * *}$ denote statistical significance at $10 \%, 5 \%$ and $1 \%$.

\section{Discussion}

In general, it is interesting to discuss the estimation results of the effect of differences in interest rates (DINT), inflation (INF), exchange rates (ER), economic growth (GRT) and foreign debt growth (GDEBT) on capital flight (CF). Except for the inflation variable, all independent variables appear to show signs of influence that are consistent with the theory, as shown in Table 6 . This is despite the fact that the value of $\mathrm{R}^{2}$ is not very satisfying and relatively low at 0.4378 . This indicates that the variation in the change in the dependent variable can be explained as roughly $43.78 \%$ by the variation in the change in the independent variables. Thus, the ability of the independent variable in explaining the dependent variable is only $43.78 \%$, while the remaining $56.22 \%$ is explained by variations in other variables which are not included in our model.

One of the results obtained by this study is interest rate difference, a variable that is a factor that determines the activity of holding domestic assets or foreign assets. Krugman and Obstfel (2009), claim that in order to obtain greater profit from the activity of holding assets in domestic assets or foreign assets depends on the interest rates offered on both assets $(i, i *)$. In other words, the difference in interest rates is the main factor in the activity of holding domestic assets or foreign assets, including the transfer of assets, whether they remain domestically as well as move abroad. The results of this study indicate that the difference in interest rates has a positive effect on capital flight in the ASEAN-8 countries. This suggests that the greater the difference in the interest rate difference between domestic savings in the ASEAN-8 countries and the treasury bill interest rates in the United States, the greater the number of sources of funds compared to the use of funds. Moreover, it indicates an outflow of capital in the ASEAN-8 countries.

The results of this study confirm the empirical results of Cuddington (1986), Vespignani (2008), Okoli and Akujuobi (2009) and Uddin et al., (2017), which state that the difference in interest rates has a positive effect on capital flight. Greater difference in the interest rates shows that the interest rate on deposits in relation to domestic assets is generally higher than the interest rate on deposits on foreign assets as reflected by the US treasury bill interest rates. Consequently, the benefits of investing in domestic asset deposits are better as compared to deposits on foreign assets in the form of treasury bill interest rates. Thus, more resident investors will hold their funds in domestic assets in the form of deposits in ASEAN-8 countries and encourage non-resident investors to also change the composition of their Dollar deposits to domestic savings, resulting in short-term inflows in Dollars which are converted into domestic savings. This results in a greater addition of foreign exchange reserve in terms of the US dollar, which will further increase the source of funds in the ASEAN-8 
countries. The results of this study have confirmed the basic motive of international portfolio investment, where a resident investor has a reason to prefer investment activities that generate a high income rather than a low income.

A further finding from the result of this study is the negative effect of the inflation rate (INF) on capital flight. This finding is in accordance with the empirical results of Ozer et al., (2013), i.e., there will be a negative effect of inflation on capital flight, where according to the empirical results, the increasing inflation will result in capital flight inflow. This signifies that the increase in inflation causes a smaller number of sources of funds compared to the use of funds or indicates that there is an inflow of capital in the ASEAN-8 countries. Thus, the greater the inflation rate, the fewer the number of sources of funds in the form of additional foreign debt, resulting in a decrease of net foreign direct investment. As we understand, the inflation that occurs can cause people's purchasing power to decrease due to increasing price levels and drive production costs to increase as well. This has resulted in the economy becoming less profitable for foreign direct investment in connection with products becoming more expensive, both for the domestic and foreign markets.

Concerning export products, inflation has driven product prices to become more expensive so that the competitiveness of export products become weak. A reduction in output and the uncertain competitiveness of export products results in a decline in export transactions so that the current account deficit is growing and the use of funds is increasing. Uddin et al., (2017) say that inflation reduces the real return on domestic assets and investors regard it as damage to their assets. This encourages investors to take their assets abroad to avoid a negative return on inflation in domestic assets and the demand for foreign assets in Dollars to be transferred abroad increases. The shift in domestic assets to foreign assets has prompted a decline in foreign exchange reserves, so that domestic foreign exchange has become increasingly reduced and limited. However, the effect of inflation on capital flight is statistically insignificant, which is an interesting point from these findings. This means that in the case of the ASEAN-8, inflation is a factor that has not been considered and does not prevent investors from making foreign direct investment in the ASEAN-8 countries, because inflation is considered to be normal. Consequently, this will encourage the flow of foreign direct investment to increase. Low inflation has implications for the confidence of foreign investors to invest in a country. Foreign investors' expectations of the government's ability to seriously maintain the stability of a low inflation rate can be a consideration for foreign investors when undertaking foreign direct investment. Moreover, if the price remains stable in the long-term in accordance with investors' expectations, this could be a reason why inflation is no longer considered by foreign investors when they are making foreign direct investment. Our finding regarding the effect of inflation on capital flight shows that the effect is positive but not significant.

The result of this study indicates that exchange rate has a positive and significant influence on outward capital flight. The direction of positive influence implies that an increase in the exchange rate (depreciation) can encourage a greater number of sources of funds compared to the use of funds or indicate capital outflow in the ASEAN-8 countries. This is the same for the opposite, where various results obtained by previous empirical studies state that the exchange rate has a positive effect on capital flight include Cuddington (1986), Ahmad and Sahto (2016) and Wujung and Mbella (2016).

For domestic investors, the depreciation of the domestic exchange rate causes a decrease in their assets measured in US Dollars, which domestic investors see as detrimental to their assets when measured in US Dollars. Therefore, domestic investors will take their assets abroad to avoid a decrease in their assets caused by the depreciation of the domestic exchange rate. Hence, this activity will reduce the foreign exchange reserves in the domestic country. However, for foreign investors, the depreciation of the domestic currency causes the exchange rate of the domestic currency to be lower in price and the value of the Dollar to increase when measured by the domestic exchange rate. For foreign investors whose input derives from the domestic market, the depreciation of the domestic exchange rate will encourage an increase in foreign direct investment. This is because foreign investors will obtain production inputs at low prices and production costs to produce products become inexpensive, so that substantial amounts of foreign investment will enter the country especially if their output orientation is for export purposes other than selling domestically. From a trade perspective, with low production costs, the prices of exported products are more competitive in foreign markets so that the performance of net exports can be improved.

Furthermore, economic growth demonstrates a positive and significant effect on capital flight in the ASEAN-8 countries. This means that the greater the economic growth in the ASEAN-8 countries, the greater the number of sources of funds compared to the use of funds. It indicates that there is an outflow of capital in the ASEAN-8 countries. The positive effect of economic growth on capital flight can be seen in the empirical results of Harrigan et al., (2002), Okoli and Akujuobi (2009), Ahmad and Sahto (2016) and Uddin et al., (2017). Thus, the greater economic growth reflects the increase in the production sectors in the economy and an increasing market share (Camba and Camba, 2019). The more the production sectors can develop, the greater the output they produce in the form of goods and services that will be abundant in the domestic market. If the domestic market is unable to absorb goods produced by the industrial sectors, as a result of which the quantity of supply exceeds 
domestic demand, then they can be sold in foreign markets so that the level of net exports increases and the current account deficit reduces. Thus, economic growth boosts economic output and export performance so that the current account deficit decreases and the value of use of funds also reduces. Increasing economic growth reveals an economy that is growing accompanied by people's increasing purchasing power, resulting in an additional increase in national savings which is greater for investment funding. Thus, foreign direct investment is attracted to invest funds domestically due to the market potential and increased profits. Furthermore, increasing foreign direct investment has contributed to an increase in sources of funding for various economic needs.

The final variable is the influence of foreign debt growth on capital flight where the coefficient is positive and significant for capital flight. This means that the higher the growth of foreign debt, the greater the number of sources of funds compared to the use of funds, which suggests that there is capital flight out of the ASEAN-8 countries. The results of this study are consistent with the empirical studies undertaken by Harrigan et al., (2002), Quazi (2004), AlFayoumi et al., (2012), Ahmad and Sahto (2016), Wujung and Mbella (2016) and Uddin et al., (2017), which state that the growth in external debt has a positive effect on capital flight. The positive results of the growth of foreign debt on capital flight can also be interpreted as the increasing role of sources of funds from foreign debt in financing development due to reduced domestic sources of capital. The substantial use of foreign debt in development has justified the scarcity of the available sources of funding in the country and the increasing role of foreign debt in development in the ASEAN-8 countries. Consequently, it increases the size of the source of funds compared to the use of funds in estimating capital flight according to the residual approach.

\section{Conclusion and Recommendations}

This study establishes that all independent variables consisting of differences in interest rates, exchange rates, economic growth and foreign debt growth have a positive and significant effect on capital flight in the ASEAN-8 countries, where each increase in the independent variable causes capital flight out or encourages capital flight, the increase in sources of funds is greater than the use of funds. These results have been consistent and support the results of previous studies. Only inflation has a negative and insignificant effect on capital flight.

The results of this study have resulted in several recommendations: first, it is necessary to keep the domestic economy continuously positive and attractive to investors, by continuing to improve the quality of infrastructure, reducing high economic costs and encouraging ease of doing business so that the investment climate grows sustainably. Second, to continue to maintain the inflation rate at the targeted rate through a mix of monetary policy, fiscal policy and real policy. Third, maintaining and encouraging the domestic exchange rate to be in a stable position and attempts to strengthen the exchange rate in the long-term must be continued. Fourth, economic growth should be directed towards producing final output that has high added value in each production sector by prioritising and optimising the use of domestic sources rather than foreign sources so as not to cause capital flight out. Fifth, work is required to reduce dependence on the use of development financing sources from abroad, notably in relation to foreign debt.

\section{References}

Ahmad, B., \& Sahto, Q. D. (2016). Determinants of capital flight in Pakistan. IBT Journal of Business Studies, 11(2), 55-64. https:// doi.org/10.46745/ilma.ibtjbs.2015.112.05

Al-Fayoumi, N. A., AlZoubi, M. S., \& Abuzayed, B. M. (2012). The determinants of capital flight: Evidence from MENA countries. International Business \& Economics Research Journal, 11(1), 1-10. https://doi.org/10.19030/iber.v11i1.6666

Batiz, F. L. R., \& Luiz, A. R. B. (1994). International Finance and Open Economy Macroeconomics. New York, NY: Macmillan Publishing Company.

Camba Jr, A. C., \& Camba, L.A. (2020). The dynamic relationship of domestic credit and stock market liquidity on the economic growth of the Philippines. Journal of Asian Finance, Economics, and Business, 7(1), 37-46. https://doi.org/10.13106/jafeb.2020. vol7.no1.37

Collier, P., Hoeffler, A., \& Pattillo, C. (2004). Aid and capital flight. IMF: Research Department.

Cuddington, J. T. (1986). Capital flight: Estimates, issues, and explanations (Vol. 58). Princeton, NJ: Department of Economics, Princeton University.

Dooley, M. P. (1986). Country-specific risk premiums, capital flight and net investment income payments in selected developing countries. International Monetary Fund Departmental Memorandum, 17.

Erbe, S. (1985). The flight of capital from developing countries. Intereconomics, 20(6), 268-275. http://dx.doi.org/10.1007/ BF02925467

Harrigan, J., Mavrotas, G., \& Yusop, Z. (2002). On the determinants of capital flight: A new approach. Journal of the Asia Pasific Economy, 7(2), 203-241. https://doi. org/10.1080/13547860220134824

Khan, M. S., \& Haque, N. U. (1987). Capital flight from developing countries. Finance and Development, 24(1), 2.

Krugman, P. R., \& Obstfeld, M. (2009). International Economics: Theory and Policy. London, UK: Pearson Education.

Liew, S. L., Mansor, S. A., \& Puah, C. H. (2016). Macroeconomic determinants of capital flight: An empirical study in 
Malaysia. International Business Management, 10(13), 2526-2534. https://doi.org/10.36478/ibm.2016.2526.2534

Nantharath, P., \& Kang, E. (2019). The effects of foreign direct investment and economic absorptive capabilities on the economic growth of the Lao People's Democratic Republic. Journal of Asian Finance, Economics, and Business, 6(3), 151-162. https://doi.org/10.13106/jafeb.2019.vol6.no3.151

Okoli, M. N., \& Akujuobi. (2009). Determinants of capital flight: The case of Nigeria. International Journal of Development and Management Review, 4(1), 233-246.

Ozer, A., Doker, A. C., \& Turkmen, A. (2013). Analysis of capital flight in developing countries: A study on Turkey between 1980 and 2010. In: International Conference on Eurasian Economies.

Quazi, R. (2004). Foreign aid and capital flight. Journal of the Asia Pasific Economy, 9(3), 370-393. https://doi. org/10.1080/1354786042000272008

Phan, N. H., \& Nguyen, L. Q. T. (2020). FDI, Corruption and development of public service sectors in ASEAN countries. Journal of Asian Finance, Economics, and Business, 7(9), 241249. https://doi.org/10.13106/jafeb.2020.vol7.no9.241

Qamruzzaman, M., Karim, S., \& Wei, J. (2019). Does asymmetric relation exist between exchange rate and foreign direct investment in Bangladesh? Evidence from nonlinear
ARDL analysis. Journal of Asian Finance, Economics and Business, 6(4), 115-128. https://doi.org/10.13106/jafeb.2019. vol6.no4.115

Schineller, L. M. (1997). An econometric model of capital flight from developing countries. Board of Governors of the Federal Reserve System Working Paper 579.

Tung, L. T., \& Thang, P. N. (2020). Impact of FDI on private investment in the Asian and African developing countries: A panel-data approach. Journal of Asian Finance, Economics, and Business, 7(3), 295-302. https://doi.org/10.13106/jafeb.2020. vol7.no3.295

Uddin, M. J., Yousuf, M., \& Islam, R. (2017). Capital flight affecting determinants in Bangladesh: An econometric estimation. International Journal of Economics, Commerce and Management 5(8), 1-26.

Vespignani, J. L. (2008). Capital flight, saving rate and the golden rule level of capital: Policy recommendations for Latin American countries. American Review of Political Economy, 6(2), 1-15.

Wujung, V. A., \& Mbella, M. E. (2016). Capital flight and economic development: The experience of Cameroon. Journal of Economics, 5(5), 1-9. https://doi.org/10.11648/j. eco.20160505.11 